\title{
A PAISAGEM CULTURAL CAFEEIRA DO SUL DO ESPÍRITO SANTO, BRASIL: A Proteção do Sítio Histórico de Muqui
}

\author{
Luciene Pessotti \\ Professora Adjunta do Departamento de Arquitetura e Urbanismo. \\ Centro de Artes, Universidade Federal do Espírito Santo. \\ luciene.pessotti@terra.com.br
}

\section{RESUMO}

O tema do presente estudo é a preservação da Paisagem Cultural enquanto forma inovadora de ensejar a proteção e a gestão do patrimônio cultural. Este artigo pretende apresentar as questões problematizadas para a proteção legal do patrimônio ambiental urbano de Muqui, situado na região sul do estado do Espírito Santo, Brasil, incluindo os elementos de sua Paisagem Cultural. O município de Muqui possui o maior acervo arquitetônico, urbanístico e paisagístico tombado no Espírito Santo, fruto da relação dos ambientes rural e urbano. O tombamento do Sítio Histórico de Muqui em nível estadual foi um importante marco na preservação do patrimônio cultural do Espírito Santo. Cabe uma reflexão criteriosa para entender porque não se deu o seu tombamento em nível nacional e como a noção de Paisagem Cultural interferiu nesse processo.

Palavras-chave: Paisagem cultural; patrimônio cultural; preservação cultural.

\section{ABSTRACT}

The scope of this study is the preservation of the Cultural Landscape as an innovative way of leading the protection and management of the cultural heritage. This article presents some elements to discuss issues related to the legal protection of the urban environmental heritage of Muqui, located in the Southern region of the state of Espírito Santo, Brazil, including elements of the Cultural Landscape. Muqui has the greatest architectural, urban and rural landscape assets protected at the state level in Espírito Santo, due to the relationship between rural and urban environments. The historical heritage site of Muqui at the state level was an important milestone in the preservation of the cultural heritage in Espírito Santo. Detailed reflection is necessary to understand the reason why the historical heritage site has not been protected at the national level yet and how the concept of Cultural Landscape interfered in this process.

Key words: Cultural landscape; cultural heritage; Cultural preservation. 


\section{PAISAGEM CULTURAL: ASPECTOS TEÓRICOS-METODOLÓGICOS PARA SUA PRESERVAÇÃO NO BRASIL}

No Brasil o projeto de preservação do patrimônio cultural e, histórico, vinculou esse processo a própria definição da categoria, que nasce vinculada ao edificado, notadamente, do monumental. Esse processo, que se deu nas décadas de 1920 e 1930, estava intimamente ligado ao Movimento Moderno e, tem em Mário de Andrade, uma das figuras centrais, que tentou construir uma identidade brasileira. A alusão a este processo demonstra que no Brasil a formação da identidade nacional, a busca de uma construção da história do país, e especialmente, a formação da política de preservação do patrimônio cultural teve bases teóricas e ideológicas.

Tais referências sempre estiveram presentes. A política de preservação cultural do Brasil, através do IPHAN, criado em 1936, sempre se balisou nos pressupostos teóricos da História, da Geografia Cultural, da Arquitetura e Urbanismo, entre outros campos de conhecimento, assim como, adotou os princípios das Cartas Patrimoniais, documentos e metodologias de intervenção da UNESCO.

No que tange as questões da preservação da paisagem, enquanto instância cultural, não foi diferente. Sendo assim, estudos, relatórios, pareceres e outros documentos técnicos elaborados pelos órgãos de preservação no Brasil, ou por eles contratados, refletem todos essa vinculação da política cultural com o conhecimento científico, além, de questões ideológicas que permeiam o conceito de nação.

O tema da preservação das paisagens culturais é na contemporaneidade uma forma inovadora de conceber a proteção e a gestão do patrimônio cultural. Tal prática é resultado das experiências desenvolvidas pela Unesco desde 1992 e das proposições estabelecidas na Convenção Européia da Paisagem.

Cabe, entretanto, uma breve reflexão nesse estudo sobre a relação do conhecimento científico, e seu arcabouço teórico-metodológico, com a política pública de preservação, adotada pelos órgão de proteção, em seus diferentes níveis, a saber, federal, estadual e municipal.

No âmbito da Geografia e da Arquitetura a abordagem conceitual de Paisagem e Paisagem Urbana apresentou ao longo dos últimos anos aspectos relevantes. Entretanto, foram por vezes convergentes e, por vezes, divergentes.

Algumas abordagens, entretanto, centraram-se nas questões morfológicas tradicionais da cidade. $\mathrm{Na}$ contemporaneidade as reflexões teórico-metodológicas indicam uma caminho comum, possibilitando maior compreensão dos fundamentos epistemológicos nas variações históricas do termo (BAHIA, 2014). Tal encaminhamento, auxilia na concepção de estudos e análises do objeto paisagem cultural.

Como contribuição ao estudo da temática, citamos os estudos de paisagem urbana de Horacio Capel, em La morfología de las ciudades (2002, p.35), que apresenta três novos temas: (1) a dinâmica morfológicofuncional urbana; (2) a compreensão da cidade como fato cultural; (3) análise tecnológica das informações espaciais.

A geografia cultural, segundo Bahia (2014) "surge das paisagens e da diversidade dos gêneros de vida, e, pela cultura institui o sujeito, a sociedade e o lugar onde é desenvolvida a coletividade", e resulta "na identidade coletiva que delineia as marcas exteriores e explica as diferenciações dos sistemas de valores nos quais se desenvolvem os grupos humanos".

A paisagem, segundo Claval (2007) carrega a marca da cultura e se constitui também como matriz do processo cultural. É objeto de estudo da Geografia Cultural e da Arquitetura e Urbanismo, campos de conhecimento que buscam interpretá-la.

No Brasil, os estudos da Paisagem Cultural adota viés fenomenológico (BAHIA, 2014), ao propor a compreensão do espaço enquanto espaço vivido. A paisagem é algo dinâmico no processo de urbanização, da rede urbana e da vida da cidade.

A cidade, sob esta perspectiva teórico-metodológica, é abordada "como um lugar distinto em suas formas de organização urbana, de manifestações cotidianas, de seus ritos e de seu ritmo: a memória cultural das marcas da interação entre cidade e seus cidadãos na experiência vivida no seu momento presente". A paisagem revela, ainda, significado que "confere ao seu morador a noção de pertencer a um lugar que é 
único, mundo vivido (...) e a um povo que tem identidade própria". A paisagem cultural "confere unidade e situa o seu habitante no tempo e no espaço" (BAHIA, 2014). Logo, cultura e cidade são entendimentos indissociáveis.

Desta forma, estudos de preservação da Paisagem Cultural no Brasil, buscam compreender e interpretar o espaço urbano considerando: (1) seus aspectos morfológico-funcionais; e, as 2) dinâmicas culturais e sua relação com o espaço.

O conceito de Paisagem no Brasil, possui forte vinculação como o conceito de patrimônio, que se constitui de bens de natureza material e imaterial.

Assim a instrumentalização de processos de preservação da Paisagem Cultural no Brasil considera os pressupostos teórico-metodológicos da transdisciplinaridade entre a Geografia, a Arquitetura e a História, pois, o estudo da paisagem urbana à investigação empírica da paisagem possui relação com a evolução urbanística das cidades.

As investigações empíricas, tais como o estudo de Muqui, enquanto estudos de caso, demonstram como se dá a abordagem da preservação da Paisagem Cultural, expondo os critérios e métodos adotados para a conservação, preservação e manutenção da memória e patrimônio cultural urbano no Brasil.

Nesse sentido, possibilitam compreender como se constitui a estruturação conceitual nos campos disciplinares, e nesta abordagem, no campo da Arquitetura e Urbanismo.

\subsection{Paisagem Cultural e proteção legal}

No Brasil, segundo Scifoni (2016), a paisagem é uma nova categoria de bem cultural no âmbito da preservação do patrimônio. Compreender os seus significados pressupõe, conforme atesta a autora (SCIFONI, 2016) problematizar experiências de preservação das instituições internacionais, aquelas que se deram no Brasil, e abordar conteúdos específicos da origem acadêmica do conceito paisagem cultural, conforme citado.

Em 1992, a Unesco define paisagem cultural como uma categoria específica do patrimônio cultural. Em 1995, o Conselho da Europa, segundo Scifoni (2016) regulamentou a sua proteção, em território europeu. Foi elaborada a Recomendação R (95) e, posteriormente, pela Convenção Europeia da Paisagem, em 2000, tem-se nova normativa. No Brasil, a Portaria $n^{\circ} .127$ de 2009, do IPHAN, cria a catergoria de paisagem cultural e institui um novo instrumento jurídico para sua proteção, denominado de chancela.

De acordo com a perspectiva do IPHAN (2014), o conceito de paisagem cultural como uma nova tipologia de reconhecimento dos bens culturais adotado no Brasil está relacionado com o fato da cidade do Rio de Janeiro ter sido a primeira área urbana do mundo a receber da UNESCO esta chancela.

Desta forma, a regulamentação da paisagem cultural no Brasil se deu em consonância com a Unesco. $O$ instrumento de preservação do patrimônio paisagístico brasileiro foi instituido através da Portaria ํo 127, garantindo proteção legal a essa nova categoria de bem cultural.

A chancela de Paisagem Cultural Brasileira é definida como "uma porção peculiar do território nacional, representativa do processo de interação do homem com o meio natural, à qual a vida e a ciência humana imprimiram marcas ou atribuíram valores" (IPHAN, 2014). Logo, possui o viés teórico fenomenóligico citado anteriormente. A proposição de preservação do IPHAN adota os pressupostos teóricos da Geografia Cultural, notadamente, nos aspectos relativos a relação que o homem estabelece na longa duração com o território.

A riqueza do Brasil caracteriza-se por sua diversidade de paisagens e pela relação excepcional entre o homem e natureza. Dessa relação, segundo a abordagem do IPHAN surge outra característica fundamental da paisagem cultural: "a ocorrência, em determinada fração territorial, do convívio entre a natureza, os espaços construídos e ocupados, os modos de produção e as atividades culturais e sociais, numa relação complementar capaz de estabelecer uma identidade que não possa ser conferida por qual quer um desses elementos isoladamente" (IPHAN, 2014). Nesta abordagem observa-se que há uma relação entre os conceitos da Geografia Cultural e da Arquitetura e Urbanismo, através do tema da preservação, notadamente, os aspectos morfológicos do espaço urbano. 
A chancela de Paisagem Cultural no Brasil implica na manutenção das caracteristicas da porção do território que o fizeram receber, assim como, no desenvolvimento de um Plano de Ação, que se formula a partir de um pacto de gestão compartilhada entre o poder público, sociedade civil e a iniciativa privada. A chancela pode ser retirada se o Plano de Gestão não for cumprido e as as características da paisagem forem degradadas ou perdidas (WEISSHEIMER, 2009). Observa-se aqui, mais uma vez, as referências da morfologia urbana e do território, pois, é imprescindível a manutenção e preservação de seus elementos constitutivos.

Seguno Nascimento (2010), a paisagem possui a marca de diferentes temporalidades. Nela está presente a "relação sociedade-natureza, aparecendo, assim, como produto de uma construção que é social e histórica e que se dá a partir de um suporte material, a natureza" (p.32). É importante, segundo a autora (NASCIMENTO, 2010), que se identifique as relações estabelecidas, nos diferentes momentos históricos, entre as comunidades locais e a natureza. O meio, notadamente o meio natural, tem uma papel importante neste processo, pois, é considerado matéria-prima para a apropriação social. Outro aspectos relevante são as relações entre comunidade-natureza, pois, a partir delas se deu "a produção dos objetos materiais (cidades, edificações, campos de cultivo) e da vida imaterial (festividades, lendas, tradições, crenças, elementos simbólicos, memória coletiva)" (NASCIMENTO, 2010, p.32).

A Convenção Europeia de Paisagem (IPHAN, 1995), publicada em 1995, atribui grande importância a percepção da população com relação a paisagem cultural. $O$ documento preconiza "que a paisagem é em toda a parte um elemento importante da qualidade de vida das populações", que as populções devem "usufruir de paisagens de grande qualidade e de desempenhar uma parte activa na sua transformação". A própria definição de Paisagem designa "uma parte do território, tal como é apreendida pelas populações, cujo carácter resulta da acção e da inter-acção de factores naturais e/ou humanos", (IPHAN, 1995) o que demonstra a assertiva acima.

Em 11 de setembro de 1995 o Comitê de Ministros, do Conselho da Europa, elabora documento sobre as políticas paisagisticas, conforme citado. Os conceitos apresentados neste documento oferecem subsidios para a compreensão do fato do Sítio Histórico de Muqui não ter sido tombado em nível nacional, conforme se abordará adiante.

Abordaremos as principais questões que tornaram inviável o tombamento de Muqui como conjunto urbano e paisagístico em nível nacional, ressaltando os princípios conceituais e legais no âmbito nacional e as inflências internacionais.

\section{O SÍTIO HISTÓRICO DE MUQUI-ES - REFLEXÕES SOBRE SEU PROCESSO DE PROTEÇÃO}

Os estudos que visavam subsidiar a proteção do sítio histórico de Muqui foram elaborados segundo os pressupostos teóricos da Arquitetura e Urbanismo, notadamente dos temas da preservação do patrimônio cultural edificado e imaterial, assim como, da Geografia Cultural e da História, notadamente, a contribuição da História Nova, que pressupõe a relevância dos estudos da história oral, da história das manifestações culturais populares, entre outros temas, que priorizam o saber vernacular.

Ressalta-se que os temas porpostos por Capel (2002), já citados: (1) a dinâmica morfológico-funcional urbana; (2) a compreensão da cidade como fato cultural; (3) análise tecnológica das informações espaciais, foram norteadores para o entendimento das dinâmicas culturais e sua relação com o espaço. A análise do estudo de caso objetiva refletir como esses recursos teórico-metodológicos possibilitaram o entendimento do valor do sítio histórico de Muqui, o que permitiu seu tombamento municipal e estadual, sem entretanto, resultar na sua proteção em nível nacional. A ausência do reconhecimento do valor histórico do bem cultural em questão pelo IPHAN retira Muqui do acervo cultural nacional do Ciclo Econômico do Café.

Este fato causou imenso impacto na dinâmica cultural do Estado do Espírito Santo e provocou debates internos nos órgãos de preservação sobre a gestão dos bens culturais locais. Tal impacto se justifica, pois, segundo dados do Centro do Comércio do Café de Vitória (CCCV, 2017), o café é a principal e mais tradicional atividade agrícola do Espírito Santo, tendo rápida expansão a partir de meados do século XIX. A cultura cafeeira é o maior gerador de recursos na maioria dos municípios capixabas, pois, sua ocorrência se dá em quase todos os municípios do Estado; sendo que, $87 \%$ do café do Espírito Santo é cultivado em pequenas propriedades rurais que têm em média 9,37 hectares; empregando cerca de 350 mil pessoas 
diretamente. O estado do Espírito Santo é o $2^{\circ}$ maior produtor de café do Brasil e o $1^{\circ}$ em produção de café conilon. Em $0,55 \%$ do território nacional o Espírito Santo produz $25 \%$ de todo o café brasileiro. Caso o Espírito Santo fosse um país, ele seria o $3^{\circ}$ maior produtor de café do mundo e o $2^{\circ}$ maior na produção de conilon/robusta.

Logo, o fato de Muqui não entrar no rol dos bens culturais do Ciclo do Café, com seu acervo urbano e rural, notadamente as fazendas, apesar de toda sua expressividade na cultura cafeeira no Espírito Santo, abre espaço para questões relativas a sua preservação e sobre a gestão do patrimônio capixaba.

Os estudos realizados pelo IPHAN-ES priorizaram somente a área urbana, sem considerar a área rural e o entorno paisagístico no primeiro momento. A questão da preservação da paisagem cultural de Muqui só é tida como relevante no processo de análise do espaço urbano, pois, constatou-se que a ocupação dos morros que existem no entorno da área urbana estavam degradando a ambiência cultural.

Percebe-se assim, que ao contratar o estudo para subsidiar o tombamento o IPHAN-ES não priorizou o recorte espacial da zona rural e do entorno da área urbana de Muqui, compromentendo, portanto, a identificação de todo seu acervo de bens imóveis, urbanos, paisagísticos, além daqueles, relativos as práticas culturais associados historicamente ao território.

As informações técnicas e históricas do Sítio Histórico de Muqui aqui abordadas constam do Relatório Técnico do Levantamento Histórico e Diagnostico Urbanístico e Arquitetônico do Sítio Histórico de Muqui - Espírito Santo, Brasil, realizado em 2008, cujas informações levantadas, foram devidamente interpretadas, sistematizadas e ilustradas. O relatório foi elaborado para o Instituto do Patrimônio Histórico e Artístico Nacional (IPHAN), sub-regional do Espírito Santo, por equipe de profissionais composta por arquitetos, historiador e estagiários em Arquitetura e Urbanismo (SOUZA; PESSOTTI, 2008).

O Levantamento Histórico e Diagnóstico Urbanístico e Arquitetônico do Sítio Histórico de Muqui Espírito Santo, Brasil, identificou as principais características urbanas, arquitetônicas e, incorporou os aspectos paisagísticos, num segundo momento, de um dos mais representativos núcleos urbanos associados ao Ciclo do Café do Estado.

O Levantamento teve como principal objetivo subsidiar o IPHAN, para instrumentalizar o processo de tombamento em nível federal do conjunto histórico e paisagístico de Muqui, e adotou os critérios metodológicos utilizados por essa instituição para levantamento de dados em campo através do uso das fichas do INBI-SU, metodologia de inventário de sítios urbanos tombados.

Ressalta-se que o objetivo do IPHAN era entender o processo histórico de formação de Muqui e, a partir do diagnóstico urbanístico e arquitetônico, decidir os critérios de sua proteção. A metodologia adotada com toda o uso de fichas padrão do IPHAN demonstra que a abordagem do estudo não pretendia ser ampla, nem conceitualmente, nem no recorte espacial.

Entretanto, posteriormente, este mesmo documento subsidiou novos estudos, elaborados pelo mesmo profissional, para a Secretaria de Estado da Cultural do Espírito Santo (SECULT-ES), em 2009, objetivando aprofundá-los e, adotar critérios para o tombamento estadual do Sítio Histórico de Muqui (PESSOTTI, 2010). O tombamento do Sítio Histórico se deu em 2012, conforme atestado na Resolução do Conselho Estadual de Cultura $n^{\circ}$ 002/2012, onde consta a demarcação da poligonal da Área de Proteção do Ambiente Cultural (APAC) (FIGURA 01), as áreas de Tombamento (AT) e, da Area de Preservação Ambiental e Paisagística (APAP) (FIGURA 02).

Observa-se, assim, que o tombameto estadual, incorporou além do casario, uma área do entorno do sítio histórico, considerando os pressupostos teóricos da preservação da paisagem cultural como relevantes no processo de preservação da ambiência de Muqui. 


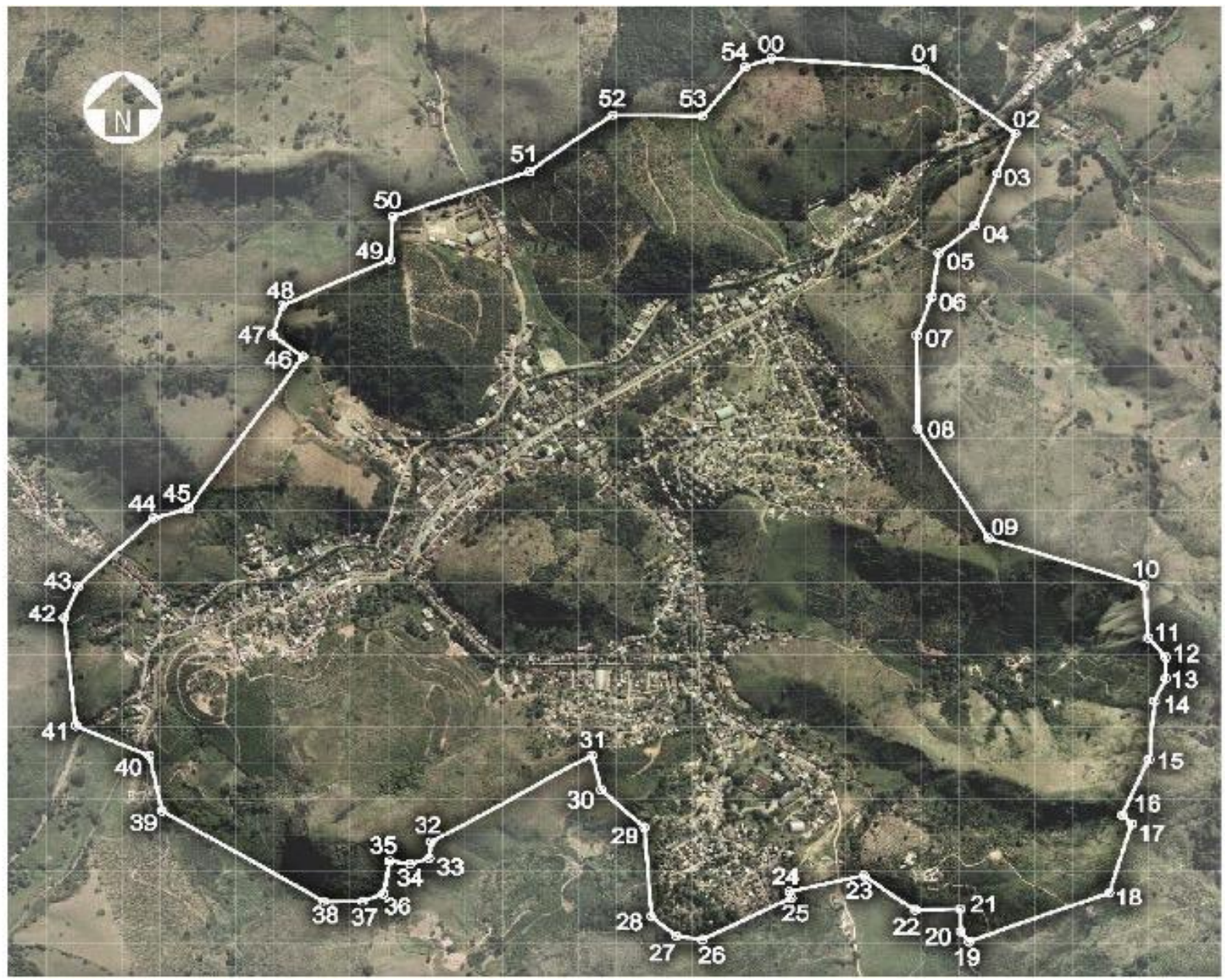

Figura 01 - Demarcação da APAC - Área de Proteção do Ambiente Cultural. Fonte: SECULT (2012) 


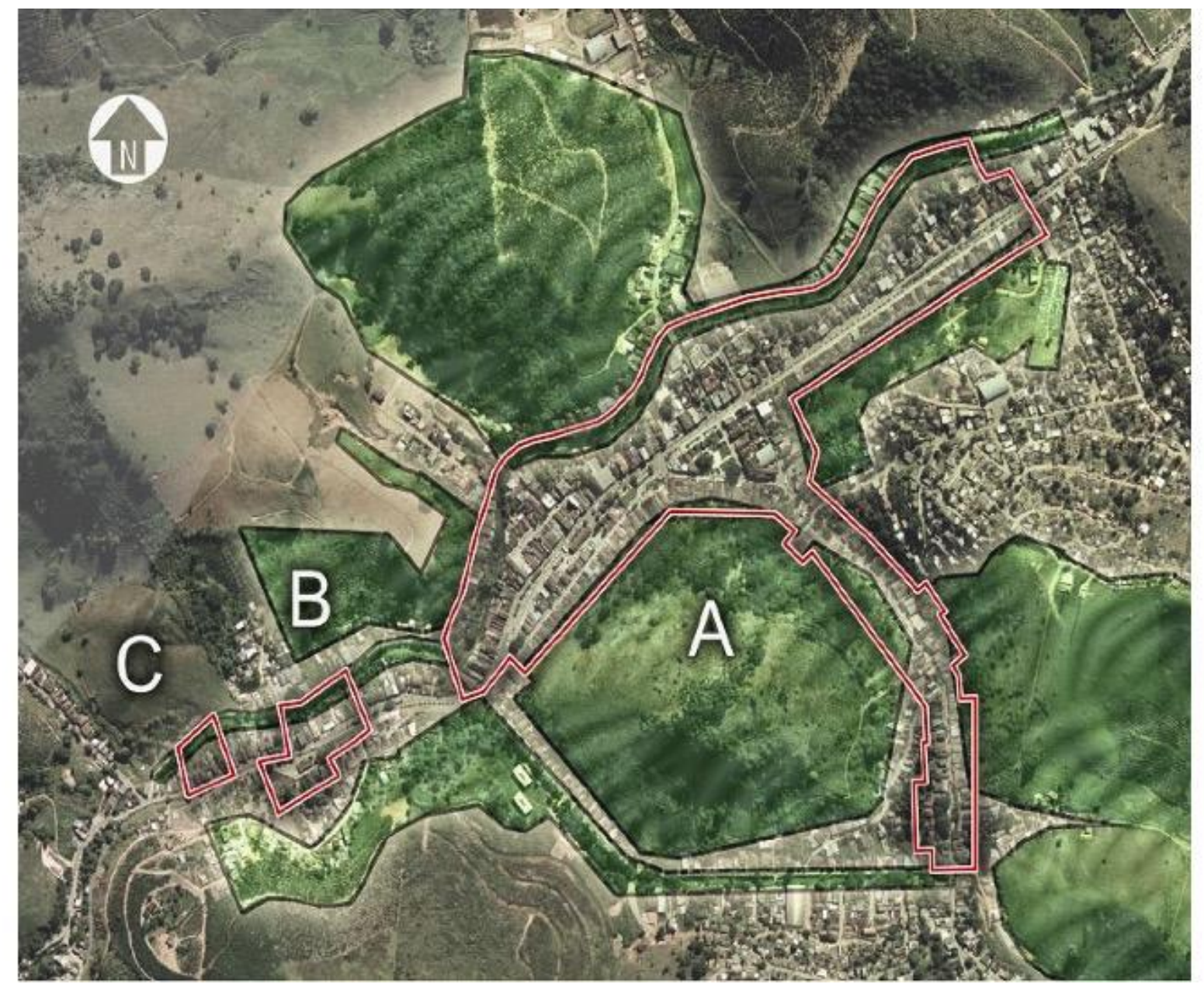

Legenda:

Área de Preservação Ambiental e Poligonal de tombamento

Paisagística (APAP) Figura 4 - Área de Preservação Ambiental e Paisagística (APAP)

Figura 02: Delimitação da Área de Tombamento (AT) e da Area de Preservação Ambiental e Paisagística (APAP). Fonte: SECULT (2012)

A noção de Paisagem Cultural foi determinante para a decisão nos dois processos de tombamento. As questões teóricas da preservação da Paisagem Cultural, fundamentadas nos campos de conhecimento da Geografia e da Arquitetura e Urbanismo, conforme abordado, não nortearam a formulação da política pública de preservação adotada pelo IPHAN para esta temática. Tal critério, entretanto, conforme observase nas figuras 1 e 2 foram adotados pela SECULT-ES, o que dá novo significado e importância a Muqui.

Apesar desta restrição teórico-metodológica, Muqui constitui-se como o maior conjunto urbano, ou seja, o maior sítio histórico protegido do Estado do Espírito Santo. No total, o número de casario inventariado em Muqui foi de 802 imóveis, e foram protegidos legalmente cerca de 263 imóveis. (PESSOTTI, 2014).

Portanto, somente no âmbito da politica estadual, o município de Muqui se caracteriza como um conjunto arquitetônico do Ciclo do Café, considerado um exemplar singular.

No entanto, em 2009 o IPHAN, em parceria com a UNESCO, contratou consultoria técnica especializada, para elaboração do Plano de Ação das cidades históricas no Espírito Santo (PAC-ES), dentre elas, Muqui.

Observa-se, assim, relevantes ações para a preservação dos bens culturais de Muqui, sendo o PAC-ES, uma ação de gestão compartilhada entre o município, o estado e o IPHAN, dele resultando o Plano de Ação para sua preservação. 
O Programa de Aceleração do Crescimento (PAC), no âmbito do governo federal, iniciou-se em 2007. É uma ação de planejamento e execução de grandes obras de infraestrutura social, urbana, logística e energética do país. Em 2013 foi criada uma linha destinada exclusivamente aos sítios históricos urbanos protegidos pelo Iphan, dando origem ao PAC Cidades Históricas. Implantado em 44 cidades de 20 estados da federação, o progragama teve investimento em obras de restauração na ordem de $R \$ 1,6$ bilhão, destinado a 425 obras de restauração de edifícios e espaços públicos (IPHAN, 2014).

Apesar de integrar o PAC das cidades históricas no Espírito Santo, Muqui não recebeu recursos para obras. Cabe ressaltar, que o município de Muqui é conhecido não só pelo seu sítio histórico, com casario arquitetônico de enorme relevância, bem como, por suas manifestações culturais, que são conhecidas em todo o Estado, e mesmo com destaque nacional.

Constata-se assim que decisões teórico-metodológicas adotadas para a elaboração de estudos que viabilizariam sua proteção nacional, incorreram, na verdade, neste impedimento.

\section{1 Aspectos Históricos da formação urbana de Muqui-Es}

O município de Muqui situa-se na região geográfica sul do estado do Espirito Santo. Sua distância até a capital do Estado, Vitória, é de $164 \mathrm{~km}$. O município possui uma extensão territorial de $327 \mathrm{~km} 2$, e encontrase aproximadamente a 235m acima do nível do mar (IBGE, 2007) (FIGURA 03).

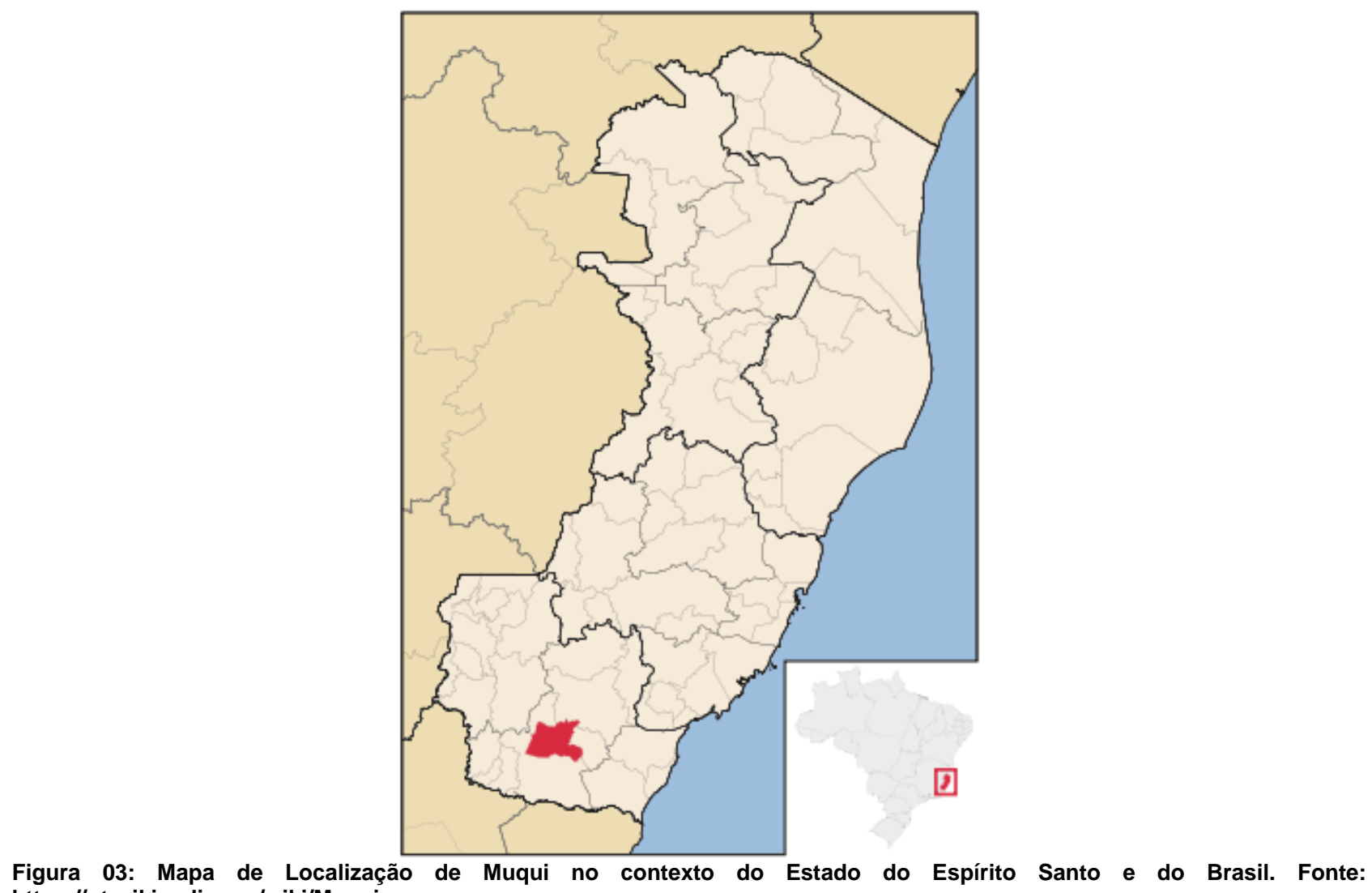

Figura 03: Mapa de Localizaça
https://pt.wikipedia.org/wiki/Muqui.

A ocupação do solo da região que iria dar origem ao município de Muqui inica-se no século XIX, aproximadamente no ano de 1850 (IBGE, 1985). As terras do município eram habitadas pelos índios Puris até fins de 1858 (IBGE, 1985).

A colonização efetiva da região se dá em meados do século XIX quando fazendeiros procedentes do Vale do Paraíba fixaram-se nas áreas baixas da serra dos Pirineus, no Vale do Sumidouro (RAMBALDUCCI, 1991).

A ocupação sul do Espirito Santo já vinha sendo explorada e ocupada desde o século XVII, consolidando este processo ao longo dos séculos XVIII e XIX. A cultura do café seria, então, um segundo momento 
neste processo de exploração econômica e que influenciou definitivamente na consolidação da ocupação da região (MENDONÇA, 1989; RAMBALDUCCI, 1991).

Estudos sobre a cultura do café afirmam que a grande extensão territorial do Espirito Santo, excetuando-se o litoral esparsamente ocupado nos séculos XVI, XVII e XVIII, começou a ser ocupada no século XIX, em virtude da cultura cafeeira (RUBIM, 1900; CUNHA, 1844).

Assim, o fator decisivo da ocupação urbana de Muqui no final da segunda metade do século XIX, teria sido a organização de diversas fazendas de café, tendo em vista que entre 1815 e 1820 o Governador Francisco Alberto Rubim incentivou e promoveu a abertura de caminhos na região sul, facilitando a entrada de tropeiros no sertão espírito-santense (RUBIM, 1900).

A primeira fazenda da região foi a Fazenda Santa Tereza, posteriormente denominada de Fazenda Santa Tereza do Sumidouro, que se tornou o epicentro da vida rural, localizada no sopé da serra dos Pirineus. Anos depois esta mesma fazenda dá origem a duas outras, Providência e Alpes. Nesta mesma bacia, surgiram, posteriormente, outras fazendas: Macedônia; Progresso; Monte Carmelo; Orange; Fortaleza; Candura e Alpes (MENDONÇA, 1989; RAMBALDUCCI, 1991).

Desta forma, a partir da implantação da Fazenda Santa Tereza do Sumidouro são organizadas diversas fazendas na região, a saber: São Francisco, as margens do Ribeirão do Muqui do Norte; Fazendas Reunidas João Vieira Fraga S.A.; Boa Esperança; Entre Morros; Santa Rita; São João; Primavera; Bom Destino; Saudade (MENDONÇA, 1989; RAMBALDUCCI, 1991). A região de Muqui se caracteriza como importante polo da economia cafeeira no Espírito Santo no século XIX e XX.

A principal consequência da organização da vida rural é o surgimento da vida urbana no entorno destas estruturas rurais. A vida urbana surge com a implantação de um estabelecimento comercial, que se constitui como um ponto de trocas comerciais para os habitantes da região. Posteriormente, estabeleceram-se outros pontos comerciais dinamizando o local (MENDONÇA, 1989; RAMBALDUCCI, 1991).

No ano de 1853, suuge as margens do ribeirão Muqui uma pequena povoação, denominada de Arraial dos Lagartos. Entre 1877 e 1887, instalou-se o comércio acima citado. Observa-se, portanto, que o fenômeno da vida rural dá origem ao fenômeno da vida urbana. Surgiram, assim, o Distrito de São Gabriel de Muquy, hoje Camará, e o Arraial dos Lagartos à beira do Ribeirão Muquy, primeiros núcleos urbanos (MENDONÇA, 1989; RAMBALDUCCI, 1991).

Desta forma, observa-se que até 1912, ano que foi criado pela Lei $n^{\circ} 826$, de 22 de outubro, o município de São João do Muquy teve toda a vida urbana organizada em torno da principal atividade econômica: o café (MENDONÇA, 1989; RAMBALDUCCI, 1991).

A vida urbana se consolida com a implantação de alguns equipamentos, a saber: (1) a criação da agência postal em 1888; (2) a chegada à vila, em 1901, das primeiras pontas de trilho da estrada de ferro; (3) a inauguração da Estação Leopoldina, em 1902, ocasião em que o Arraial passa a se chamar Muquy. Neste mesmo ano foi construída a primeira capela religiosa.

As transformações econômicas que ocorreram no século XIX foram observadas por Júlia Lopes de Almeida, romancista e contista, que visitou o Espírito Santo durante o governo Jerônimo Monteiro (1908-1912). Segundo a romancista, no Estado do Espirito Santo, havia um grande movimento de progresso e de transformação. O Governo viabilizava a navegação a vapor pelos rios Doce e Itapemirim, facilitando a ocupação do interior, bem como, as construções de estradas de ferro que atravessam regiões férteis; e tudo em vários pontos do Estado, simultaneamente (SOUZA; PESSOTTI, 2008).

Tais transformações possibilitaram que em pouco tempo um pequeno arraial se transformasse em um núcleo urbano que viria se organizar e ter vida política e administrativa própria. O território atual de Muqui fazia parte de Cachoeiro de Itapemirim, figurando como distrito de São Gabriel de Muqui. Em 22 de outubro de 1912 Muqui foi elevada à categoria de município, e sua sede foi elevada à categoria de cidade, através da Lei de no 1.385 de 05 de julho de 1923. Em 24 de junho de 1955 foi criada a comarca de Muqui, selando sua emancipação jurídica com sua instalação em 16 de agosto do mesmo ano (MENDONÇA, 1989).

Em virtude do acentuado crescimento econômico das fazendas da região de Muqui, o núcleo urbano que surge de forma incipiente para atender trocas comerciais torna-se uma vila e, posteriormente, um 
município onde se ostentava a riqueza do café. Ao longo de todo esse período histórico Muqui se destacou como polo econômico e cultural, bem como, ostentou a riqueza erudita do sul do Estado do Espírito Santo, com uma elite que valorizava a música, a poesia e as artes plásticas em geral. O investimento do retorno dos lucros advindos do café foram empregados não só na arquitetura e no núcleo urbano, mas, também, nas artes em geral.

\subsection{História e territorialidades: a relação do patrimônio imaterial com o espaço urbano}

Uma dos aspectos relevantes no tombamento de Muqui foi a riqueza de seu patrimônio imaterial. O município de Muqui é conhecido não só pelo seu sítio histórico, com casario arquitetônico de relevância local, bem como, por suas manifestações culturais, que são conhecidas em todo o Estado, e mesmo com destaque nacional.

Uma festa tradicional, que é o Carnaval do Boi Pintadinho, é uma das principais atrações culturais e tem suas raízes nas festas do Boi Bumbá, provavelmente em decorrência das atividades de criação de gado na região, desde o período colonial, e em Muqui, especificamente, a partir da década de 1950 (SEBRAE, 2005).

Assim, a festa do Boi Pintadinho ainda estaria relacionada a presença do carro do boi na região (LOBATO, 1968). O carnaval é composto de cerca de 20 blocos, cada um com seu boi, que percorrem o centro histórico da cidade com todo um ritual que faz parte das tradições populares do Brasil.

Destaca-se também a Folia de Reis. Existem no município cerca de doze grupos de Folias de Reis. Além disto, existem vinte e quatro grupos de bois pintadinhos, um jaguará de São Pedro e um Caxambu, o que totaliza cerca de trinta e oito grupos folclóricos em atividade no município. Esses grupos promovem os três mais importantes eventos culturais do município, que geram grande movimentação para a economia local: Encontro Nacional de Folias de Reis, Carnaval Folclórico e Entressafra do Boi Pintadinho.

Sendo assim, é notável o rico patrimonio material e imaterial do Sítio Histórico de Muqui e sua relação com outras expressões semelhantes de caráter nacional (FIGURAS 4, 5, 6, e 7).

Este conjunto de bens culturais integra um dos mais ricos acervos do Espírito Santo, e na ocasião das manifestações culturais têm-se a vivência da tradições no território com envolvimento de toda a comunidade local, com participação de adultos e crianças, o que vem garantindo a sua perpetuação.

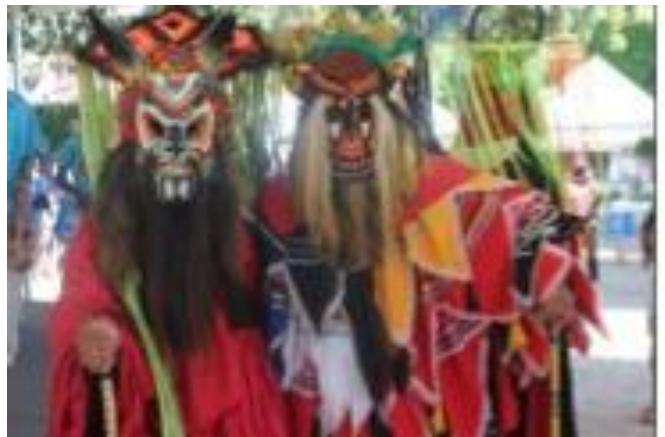

Figura 04: Folia de Reis em Muqui. Homens mascarados. Rica expressão da cultura popular nacional que tem forte vínculo com o espaço histórico. Patrimônio intangível. Fonte: (SOUZA; PESSOTTI, 2008)

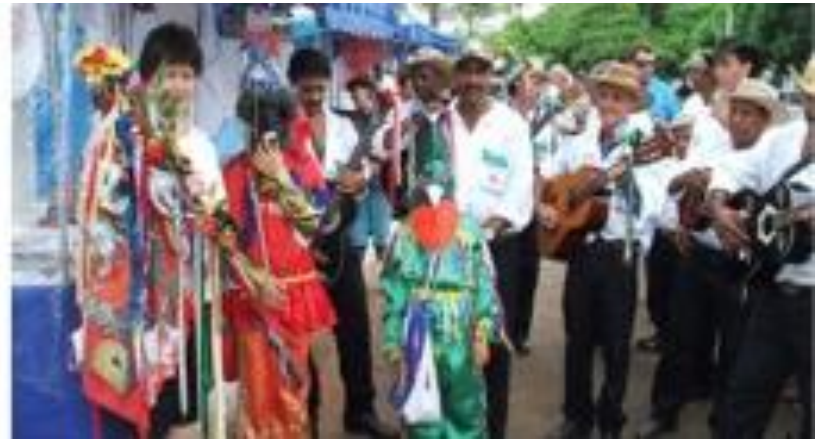

Figura 05: Mascarados e banda de música. Folia de Reis em Muqui. Rica expressão da cultura popular nacional que tem forte vínculo com o espaço histórico. Patrimônio intangível. Fonte: (SOUZA; PESSOTTI, 2008) 


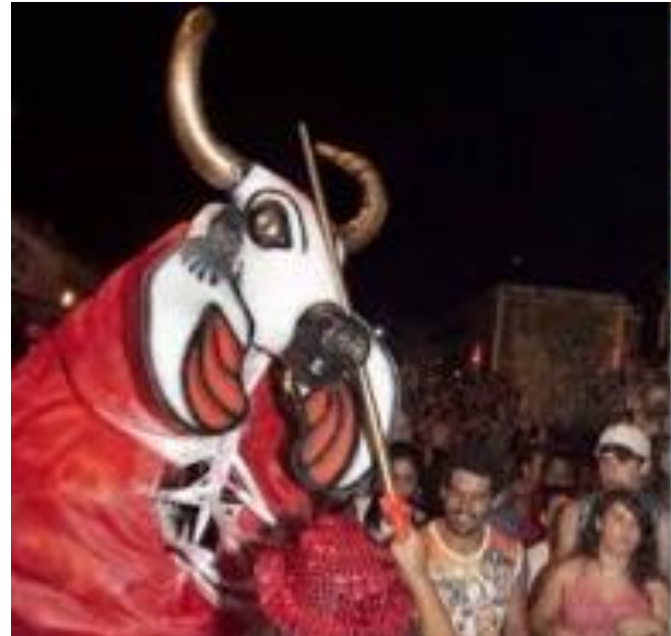

Figura 06: Fonte: (SOUZA; PESSOTTI, 2008) espaço histórico. Patrimônio intangível.

\subsection{Patrimônio cultural preservado}

Apresentaremos, então, como os critérios de preservação da Paisagem Cultural adotados pelo IPHAN definiram o resultado final do tombamento do Sítio Histórico de Muqui.

Dando continuidade ao trabalho realizado pelo IPHAN, o Governo do Estado do Espírito Santo realizou o tombamento do casario do Sítio Histórico de Muqui, considerando a relevância do conjunto arquitetônico do Ciclo do Café.

O Sítio Histórico de Muqui, conforme abodado, é um dos conjuntos urbanos mais significativos, associado ao ciclo econômico do café, com exemplares arquitetônicos relevantes na história da arquitetura do Espírito Santo, e do Brasil, pela relação do ambiente rural com a produção urbana, com casario em diferentes estilos, notadamente o Art Déco e o Ecletismo.

Visando a análise do seu estado de conservação e estabelecer parâmetros de proteção legal para Muqui, o IPHAN, em 2008 iniciou o processo de estudo do Sítio Histórico, já citado.

Para a realização deste serviço o IPHAN orientou a aplicação do INBI-SU, que se constitui numa metodologia de inventário de sítios urbanos tombados, desenvolvida pelo próprio órgão, e que se desenvolve com três abordagens distintas e inter-relacionadas: (1) a pesquisa histórica, coletando informações gerais sobre a formação e o desenvolvimento do sítio; (2) os levantamentos físicoarquitetônicos, registrando as características e condições físicas de cada edificação; e, (3) através das entrevistas com os moradores e usuários, abordando dados socioeconômicos e registrando as opiniões sobre a cidade onde vivem. Em 2008 foram desenvolvidas as duas primeiras abordagens, com o levantamento do conjunto arquitetônico por quadra, visando analisar suas características morfológicas e formais, com vistas a preservação e manutenção de seus aspectos relevantes (volumetria, estilo, afastamentos, etc.).

No ano de 2009, o Governo do Estado do Espírito Santo, através da Secretaria de Estado da Cultura (SECULT), inicia o processo de tombamento do Sítio Histórico de Muqui, com a aplicação da mesma metodologia de inventário de sítios urbanos desenvolvida pelo IPHAN, já com atualizações divulgadas no I Fórum Nacional do Patrimônio Cultural, ocorrido em dezembro deste mesmo ano na cidade de Ouro Preto. Para tanto, foi aprofundado o Inventário de Conhecimento do acervo arquitetônico e urbanístico de Muqui, objetivando a análise da caracterização externa dos imóveis com vistas a sua proteção legal, seja através do instrumento do tombamento, seja através do instrumento do inventário.

\subsection{Aspectos metodológicos e legais}

Para dar continuidade as ações de proteção e preservação do Sítio Histórico de Muqui foi realizado a partir do mês de janeiro de 2009, o Inventário de Conhecimento de todos os seus imóveis urbanos que apresentam valor histórico e estético. 
Um Inventário de Conhecimento (ou de varredura), conforme define o órgão que o elaborou, o IPHAN, é qualquer estudo que vise conhecer o universo de bens culturais de determinada região ou relacionados com determinado tema, que identifique e cadastre as ocorrências materiais ainda existentes, apontando a necessidade de estudos mais detalhados.

Os inventários de conhecimento ou varredura funcionam como um mapeamento abrangente do patrimônio cultural, cujo objetivo final é sua proteção e valorização. Para a proteção, devem ser utilizados os diversos instrumentos existentes, tanto em nível federal, como estadual e/ou municipal, aplicados de forma compartilhada.

Para atingir os objetivos do Inventário de Conhecimento foram utilizados os seguintes procedimentos metodológicos, a saber:

1) Análise das transformações do Sítio Histórico de Muqui, notadamente, seu acervo arquitetônico, urbanístico e, num segundo momento, paisagístico, considerando as informações do Levantamento Histórico e Diagnóstico Urbanístico e Arquitetônico do Sítio Histórico de Muqui - Espírito Santo, Brasil, coordenado pela 21 SR IPHAN, em 2008;

2) Levantamento fotográfico da(s) fachada(s), especialmente as fachadas frontais, ou aquelas que demonstram o aspecto formal/estilístico do edifício histórico;

3) Identificação dos materiais construtivos externos;

4) Breve descrição arquitetônica do edifício histórico, visando registrar os traços mais relevantes de seus aspectos tipológicos, morfológicos e estilísticos;

5) Análise geral do estado de conservação e do grau de descaracterização dos imóveis;

6) Sistematização das informações em fichas padrão utilizadas no INBI-SU, de autoria do IPHAN, e disponibilizadas para os estados e municípios de todo o Brasil, através do Sistema Integrado de Conhecimento e Gestão - SICG;

O Sistema Integrado de Conhecimento e Gestão - SICG, conforme definição do IPHAN, é um instrumento desenvolvido para integrar os dados sobre o patrimônio cultural, com foco nos bens de natureza material, reunindo em uma base única informações sobre cidades históricas, bens móveis e integrados, edificações, paisagens, arqueologia, patrimônio ferroviário e outras ocorrências do patrimônio cultural do Brasil.

Após este levantamento e sistematização das informações foram identificados os imóveis mais relevantes e em melhor estado de conservação, considerando, também, aqueles que possuem menor grau de descaracterização no conjunto da obra.

De acordo com o relatório do Inventário de Bens Móveis elaborado em 1999 pela Prefeitura Municipal de Muqui, a justificativa do tombamento municipal do casario se justifica por duas vertentes conceituais: a econômica e a estilística.

Cabe ressaltar, que uma das principais potencialidades e instrumento de valorização de Muqui é sua diversidade tipológica, devido as diferentes fases de construção de seu conjunto urbano, influenciadas pelos ciclos econômicos, onde diferentes estilos foram utilizados.

No total, o número de casario que foi inventariado em Muqui na década de 1990 é de 542 imóveis. Dentro deste universo, 164 imóveis são tombados, em cinco níveis distintos de proteção, que perfaz $29,77 \%$ do total inventariado; 85 imóveis foram notificados e não tombados, em cinco níveis distintos de interesse de preservação, que perfaz $15,43 \%$ do total inventariado; 273 imóveis não foram notificados, em cinco níveis distintos de interesse de preservação, que perfaz 49,55\% do total inventariado; 6 imóveis não notificados, não tombados, que perfaz $1,08 \%$ do total inventariado; 20 imóveis que foram inventariados, mas não foi definido o nível de proteção, que perfaz 3,63\% do total inventariado; 3 terrenos, em dois níveis distintos de interesse de preservação.

Deste universo percebe-se que uma parcela significativa de imóveis que não foram tombados, mas identificados com níveis distintos de proteção. Neste sentido, coube, como uma avaliação mais profunda do 
casario inventariado e o estabelecimento de novos critérios de análise para sua preservação, visando uma conclusão sobre a proteção do acervo arquitetônico de Muqui.

Visando a proteção legal do acervo material (bens móveis e imóveis) do município, notadamente, do casario histórico, foi promulgada no âmbito municipal a Lei $n^{\circ}$ 070/99, publicada em 06 de outubro do mesmo ano. A lei "Dispõe sobre o Tombamento do Patrimônio Histórico e Artístico do Município de Muqui e dá outras providências", e ressalta a necessidade de preservação de bens imóveis, e os sítios naturais e paisagens, que deverão ser registrados em Livros de Tombo da prefeitura.

Na etapa, realizada pela SECULT-ES, foram identificados através do Inventário de Conhecimento todos os imóveis com características históricas e formais relevantes, ainda que as edificações apresentem descaracterizações e intervenções que comprometam a sua integridade.

Assim, após o levantamento em campo foram selecionados imóveis para proteção através do instrumento do tombamento, e outros através do instrumento do inventário.

No total foram protegidos pelo instrumento do tombamento 173 imóveis e pelo instrumento do inventário 90 imóveis. Desta forma, Muqui constitui-se o maior conjunto urbano, ou seja, o maior sítio histórico protegido do Estado do Espírito Santo, com 263 imóveis identificados com valor históricos e estético.

Em 2009, conforme citado, o Plano de Ação das cidades históricas no Espírito Santo (PAC-ES), insere Muqui nas ações de planejamento. Ressaltamos algumas ações previstas no âmbito da PAC-ES: (1) implantação de um projeto sustentável de desenvolvimento turístico do município; (2) recuperação dos edifícios e dos espaços públicos condicionada à garantia que promova atividades econômicas, sociais e culturais; (3) apoio e divulgação de práticas, celebrações, festejos, tradições religiosas, etc. independe do local de realização (ex. Praça, centro de Apoio à estruturação de atividades produtivas nas cidades históricas), com ênfase para as atividades tradicionais.

No âmbito do PAC-ES não foram previstas ações de preservação e proteção da área rural e da paisagem cultural.

Logo, as proposições para Muqui deveriam estar afinadas com os princípios da politica cultural nacional e internacional, notadamente, a preservação e proteção da paisagem cultural, considerando que o Brasil é signatário dos acordos e recomendações firmados fora de sua jurisprudência.

\subsection{Principais critérios para o tombamento do casario do Sítio Histórico de Muqui}

Inicialmente ressalta-se que o tombamento é um ato administrativo realizado pelo Poder Público, ou seja, pela União, pelo Governo do Estado ou pelo município. O tombamento tem como objetivo preservar, através de legislação específica, bens de valor histórico, cultural, arquitetônico e ambiental. O instrumento legal do tombamento é um dos recursos mais utilizados para a preservação da memória e para que os bens culturais não sejam destruídos ou descaracterizados. Logo, o tombamento auxilia para que as intervenções em bens culturais venham acompanhadas de critérios específicos voltados para sua preservação e conservação.

Neste sentido, foram adotados os seguintes critérios, como premissas necessárias para o tombamento dos bens culturais imóveis de Muqui. Cita-se, notadamente, a presença dos seguintes atributos relativos ao bem cultural, a saber:

\subsubsection{Autenticidade}

A autenticidade é considerada como um atributo do bem cultural, que confere importância ao seu valor como documento. A autenticidade não está relacionada apenas ao material construtivo, mas também à forma estilística (composição estética), técnica construtiva, função e lugar de implantação paisagística. A autenticidade quando associada com o bem cultural, é uma premissa que nos permite relacionar o conhecimento profundo dos elementos construtivos, tipológicos e ornamentais das edificações a uma cultura de uma determinada época. A matéria autêntica é um importante atributo dos bens culturais materiais, que atesta a sua singularidade e sua permanência no tempo. No que tange ao espaço urbano, a 
autenticidade se caracteriza pela relação dos monumentos arquitetônicos e a paisagem que o envolve, e mesmo das áreas não edificadas, como nos jardins e outros elementos compositivos do espaço.

A autenticidade é considerada no âmbito da preservação do patrimônio cultural como um dos principais atributos necessários para o reconhecimento de valor dos bens culturais, pois, Ihe confere a noção de veracidade, ou seja, o bem cultural é reconhecido também pelo real valor de todos os seus elementos constitutivos originais.

\subsubsection{A instância histórica}

Segundo a Teoria da Restauração formulada por Cesari Brandi, a obra de arte, como podem ser definidos os bens culturais imóveis, possuem dupla historicidade. No primeiro aspecto o bem cultural arquitetônico deve conter referencias históricas que o remetam a um local de implantação e a um momento temporal da sua criação, e, também, a sua relação com o seu autor ou construtor naquele momento histórico. $\mathrm{Na}$ segunda instância o bem cultural deve ter uma relação de significado no tempo atual, a partir da forma como ocorre a sua percepção e sua interação com o a dinâmica social em que se encontra.

Em se considerando que os bens imóveis arquitetônicos e os espaços urbanos têm um caráter fixo, imutável em sua implantação geográfica, deve-se considerar, por este viés teórico, que o surgimento de um do casario (momento de criação), isoladamente como edificação, ou em conjunto (arquitetônico), tem uma relação de significado com as condicionantes do momento socioeconômico que nortearam a sua construção (ciclo econômico do café) e a formação urbana onde se insere. Deve-se considerar também a forma com que a implantação no sitio geográfico determinou a relação dos seus elementos morfológicos (ruas, edificações, praças, entre outros) criando uma ambiência em que se apresenta. Contemporaneamente o Sítio Histórico de Muqui tem uma relação peculiar de percepção, valorizada pela relação da morfologia urbana com o casario, e em especial com a geomorfologia local. Pode-se ainda associar-se a este aspecto a apropriação sociocultural diferenciada e própria do tempo atual, pois, a população local possui fortes referências com o processo de consolidação do sítio histórico.

\section{SÍTIO HISTÓRICO DE MUQUI - QUESTÕES DO IMPEDIMENTO DO TOMBAMENTO PELO IPHAN}

O tombamento do Sítio Histórico de Muqui ocorreu apenas em âmbito estadual. Na esfera nacional não houve sua proteção legal enquanto conjunto urbano e paisagístico. Apesar de ações de inventário e de preservação do patrimônio cultural, o Iphan não fez tombamento de nenhum imóvel.

$\mathrm{Na}$ ocasião da elaboração dos estudos de levantamentos e diagnósticos de Muqui, primeiramente em 2005, e posteriormente em 2008, houve discussão acerca do comprometimento do valor de sua paisagem cultural, em virtude de inúmeras interferências espúrias.

Retomando os conceitos apresentados pelo Comitê de Ministros, do Conselho da Europa, ressaltamos o de Poluição Visual: "degradação ofensiva "a visualidade resultante ou de acúmulo de instalações ou equipamento técnico (torres, cartazes de propaganda, anúncios ou qualquer outro material publicitário) ou da presença de plantação de árvores, zona florestal ou projetos construtivos inadequados ou mal localizados" (IPHAN, 1995).

As causas dos impactos negativos na paisagem, segundo o documento, podem vir dos complexos vínculos dos indivíduos com seu meio ambiente, tais como: (1) o uso insustentável de recursos naturais do solo, subsolo água e atmosfera; (2) desenvolvimento urbano insuficientemente planejado e executado (3) negligência ou inadvertência sobre o valor das paisagens culturais, devido a falta de informação e educação (IPHAN, 1995).

Considerando a data da publicação do documento (1995), e a data dos estudos sobre Muqui (2000-2009), e também a atuação do IPHAN em consonância com as convenções internacionais sobre a preservação cultural, sabe-se que a decisão do órgão nacional foi balisada nos seguintes critérios:

1. O comprometimento da qualidade do ambiente histórico, notadamente, a área urbana, em virtude de diversas intervenções espúrias no casario (FIGURA 08);

2. A construção de edificações inadequadas no ambiente histórico urbano (FIGURA 09) 
3. Infra-estrutura urbana inadequada (saneamento básico) que interfere diretamente no meio ambiente (FIGURA 10);

4. Desenvolvimento urbano insuficientemente em virtude da ausência de planejamente condizente com o sítio histórico, acarretando ocupação urbana inadequada no entorno do sítio histórico, impactando negativamete na paisagem cultural (FIGURAS 11 e 12);

5. Falta de conscientização da população sobre a importância da preservação e proteção do patrimônio cultural.

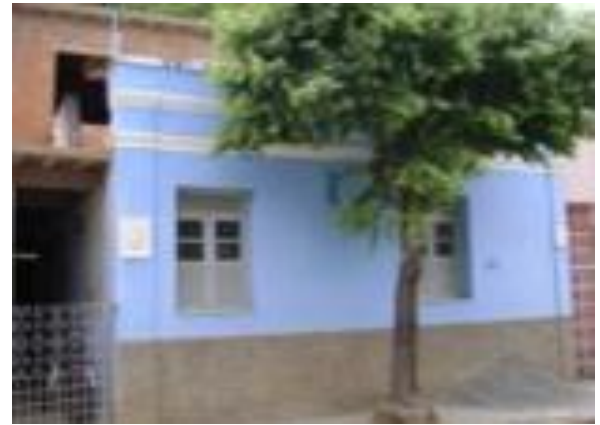

Figura 08: Edificação de um pavimento com duas aberturas de janela na fachada principal, com afastamento lateral, onde há inserção de um portão. Uma platibanda simples e retangular coroa a fachada do imóvel e é marcada pela presença de um friso horizontal. Marcação de colunas nas laterais do imóvel. Barramento com acabamento em chapisco. Inserção de novo volume que rompe com a tipologia arquitetônica e descaracteriza o imóvel histórico.

Fonte: (PESSOTTI, 2010).

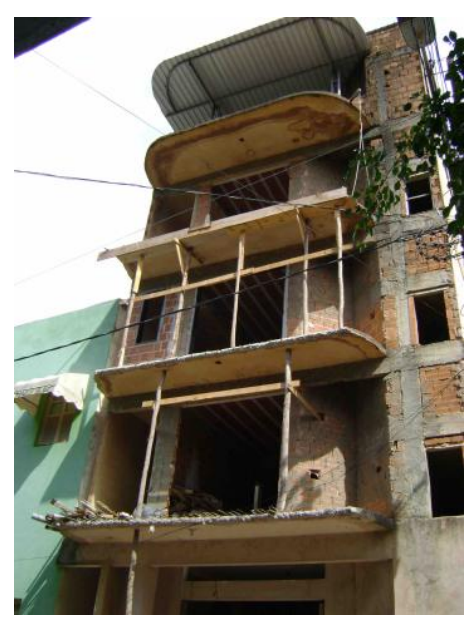

Figura 09: Edificação contemporânea que rompe a escala do casario histórico e rompe com equilíbrio formal do sítio histórico pela adoção de partido arquitetônico incompatível com as referencias estéticas do local.

Fonte: Imagem - acervo da autora

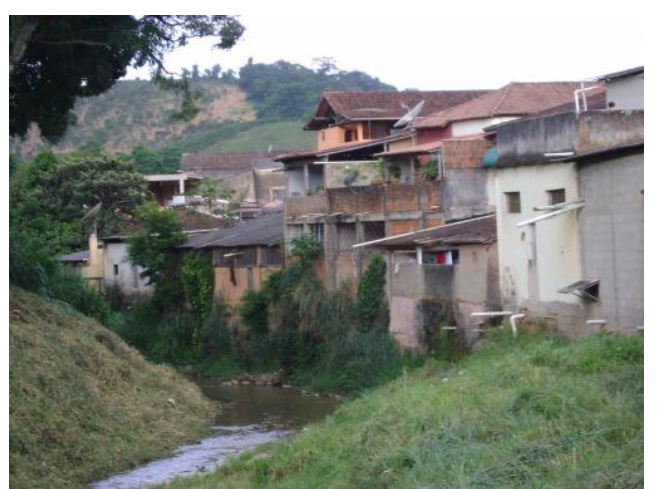

Figura 10: Degradação ambiental causada pela ocupação desordenada e pelo despejo de rede de esgoto no rio localizado no Sítio Histórico. A ocupação de fundo de lote nas quadras com edificações espúrias compromete a estrutura fundiária histórica e rompe com o lógica original de ocupação urbana.

Fonte: Imagem - acervo da autora 

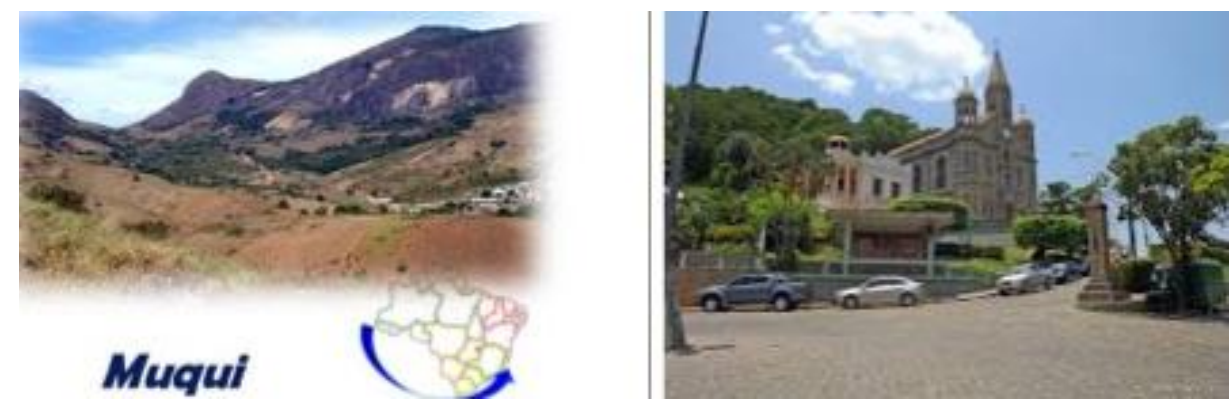

Figura 11: Muqui está localizada entre morros. Seu casario histórico e outros edifícios singulares tem uma rica e expressiva relação com a paisagem cultural.

Fonte: imagens - acervo da autora.

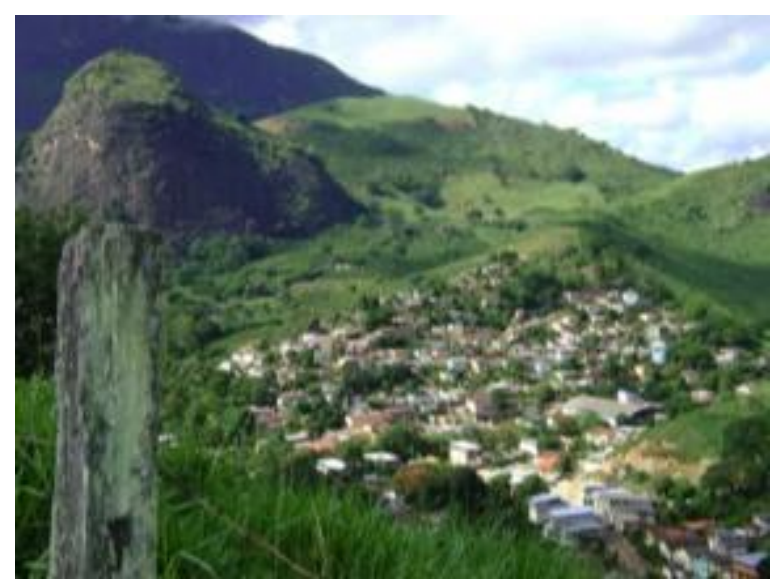

Figura 12: Ocupação desordenada nos morros do entorno do sítio histórico causando impacto negativo na paisagem cultural.

Fonte: imagem - acervo da autora.

Cabe, portanto, algumas considerações sobre o Patrimônio ambiental urbano de Muqui. Segundo Castriota (2007) em sua abordagem sobre a problemática da intervenção sobre conjuntos urbanos, o conceito contemporâneo de patrimônio ambiental urbano, é a "matriz a partir da qual podemos pensar hoje a preservação do patrimônio, sem cair nas limitações da visão tradicional". O conceito amplia o entendimento dos conjutos urbanos no sentido histórico e cultural, noção essa que se amplia para o conceito de paisagem urbana, a partir da percepção de seu conjunto, "valorizando não apenas monumentos 'excepcionais', mas o próprio processo vital que informa a cidade". Além disto, há que se considerar a relação de grupos de edificações históricas, com o território, a geomorfologia, a paisagem urbana e aos espaços públicos.

Assim a abordagem de patrimônio ambiental urbano, extrapola a percepção isolada da edificação, do monumento isolado, "testemunho de um momento singular do passado, mas torna-se necessário, antes de mais nada, perceber as relações que os bens naturais e culturais apresentam entre si, e como o meio ambiente urbano", fruto dessas relações.

O autor (CASTRIOTA, 2007) ressalta a importância da articulação destes elementos morfológicos em termos de qualidade ambiental, advertindo que preservar o patrimônio ambiental urbano é conservar o "equilíbrio da paisagem, pensando sempre como inter-relacionados a infra-estrutura, o lote, edificação, a linguagem urbana, os usos, o perfil histórico e a própria paisagem natural", e sua relação com a qualidade de vida e das possibilidades de desenvolvimento do homem.

Assim ao observamos o rico acervo do Sítio Histórico de Muqui (FIGURAS 13, 14, 15 e 16), percebemos o contrates destes exemplares com os elementos espúrios já ilustrados.

Esta relação compromete a riqueza da paisagem cultural e inviabilizou o tombamento em âmbito federal. Entretanto, por se tratar de um dos mais importantes núcleos urbanos relacionados com o Ciclo do Café no Estado do Espírito Santo, ocorreu seu tombamento estadual, e foi elaborada um conjunto de normas para a proteção do patrimônio ambiental de Muqui. 


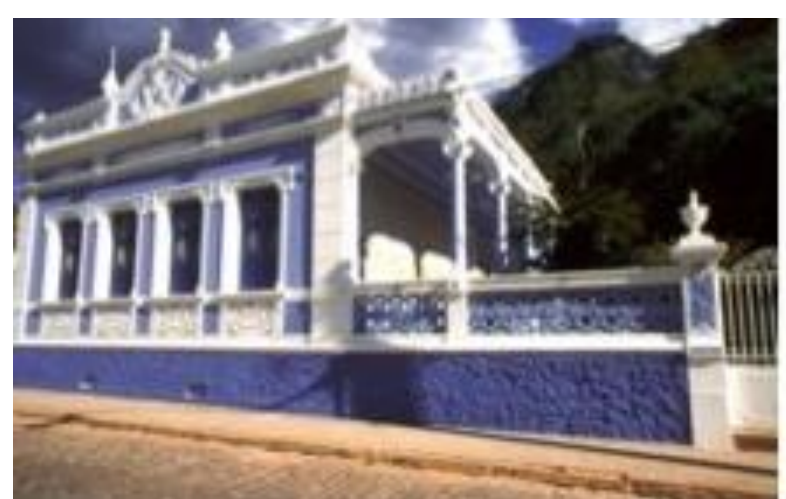

Figura 13: Casario histórico preservado. Nota-se que a tipologia do edifício, com quintal e varanda lateral, remete a ocupação do século XIX no Brasil.

Rico exemplar do Ciclo do Café. Fonte: imagem - acervo da autora

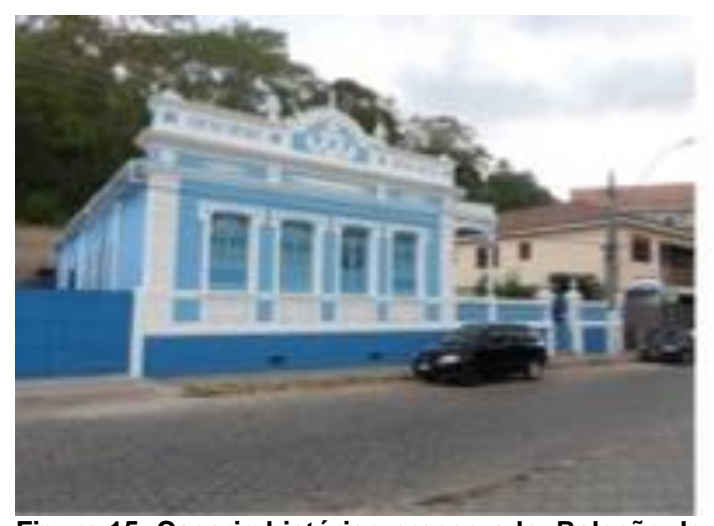

Figura 15: Casario histórico preservado. Relação do Imóvel com o natureza existente nos morros que circundam o sítio histórico.

Rico exemplar do Ciclo do Café.

Fonte: imagem - acervo da autora

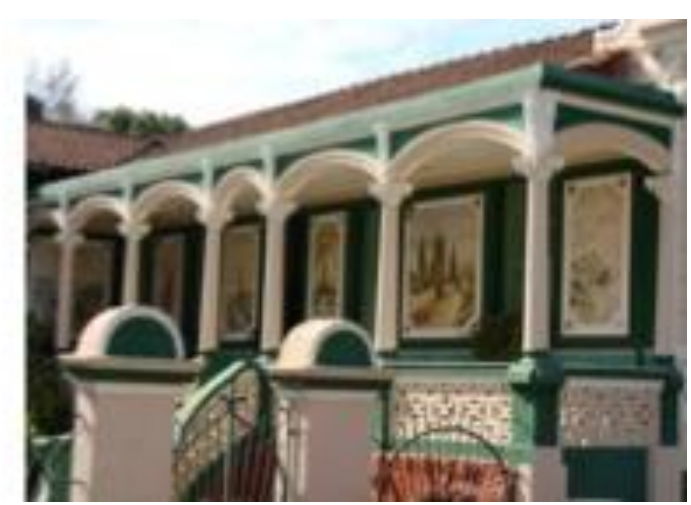

Figura 14: Casario histórico preservado. Imóvel com varanda com ricos painéis de azulejos pintados, típicos do local. Rico exemplar do Ciclo do Café. Fonte: imagem acervo da autora

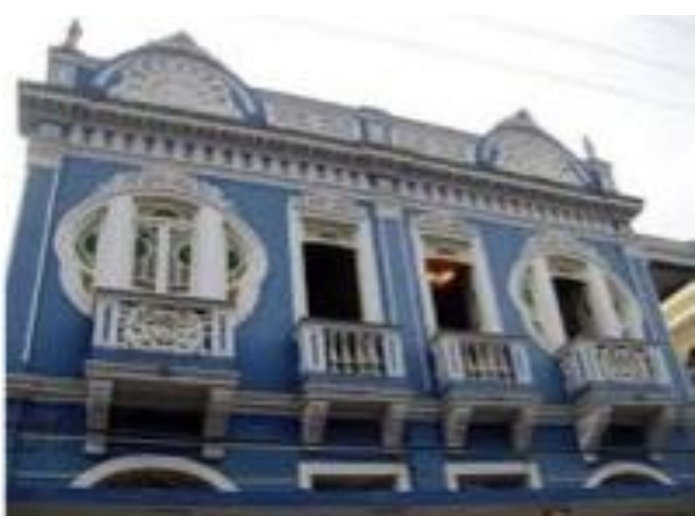

Figura 16: Casario histórico preservado. Rico exemplar do Ciclo do Café. Imóvel de dois pavimentos, com residência na parte superior e comércio no térreo. Tiplogia arquitetônica do século XIX. Fonte: imagem - acervo da autora

\subsection{Considerações finais}

Conforme citado na abordagem inicial, no Brasil os pressupostos científicos de determinados campos de conhecimentos são adotados como pressupostos teórico-metodológicos para adoção de critérios de proteção, entre outros procedimentos técnicos.

No tema da preservação da paisagem cultural não foi diferente. Observou-se a influência da experiência européia, e do amadurecimento das renovações teóricas, em especial, da Geografia Cultural e da História. Sendo assim, ressaltamos que os estudos para o tombamento de Muqui refletem um importante avanço nas questões metodológicas, conceituais e culturais, pois, incorporam todo o amadurecimento e riqueza do debate contemporâneo no que tange a salvaguarda de conjuntos históricos urbanos e da paisagem cultural no Brasil.

A relevância do acervo do patrimônio ambiental urbano de Muqui, entretanto, não integra o acervo de bens do Ciclo do Café em âmbito nacional.

A diferença de abordagem, conceitos e métodos empregados pelo IPHAN e pela SECULT, ou seja, pelas instâncias da política cultural federal e estadual, divergiram em alguns aspectos relevantes. O principal aspecto relaciona-se com a valoração da paisagem como categoria, como bem cultural.

Tal abordagem comprometeu aspectos relevantes da preservação de Muqui e de sua zona rural, pois, excluiu a área e o acervo arquitetônico, notadamente as sedes das fazendas, do processo de proteção, desde sua origem pelo IPHAN. 
Sabe-se que tombamento não garante a preservação ao longo do tempo, mas, é, ainda no Brasil, o principal instrumento de salvaguarda, pelo seu caráter simbólico, além do alcance jurídico, já consolidado.

Sendo assim, o caso de Muqui expõe uma fratura na política cultural brasileira, apesar dos avanços citados. Questões teórico-metodológicas divergentes excluiram importantes bens culturais do acervo protegido de Muqui, o que compromete seu entendimento e percepção como conjunto.

No entanto, tais fraturas abrem caminho para o entedimento dos processos e encaminhamentos adotados na proteção e preservação da paisagem cultural no Brasil, a partir dos critérios e soluções adotados.

Apesar destas divergências, Muqui integra o maior conjunto urbano protegido do Espírito Santo, referenciando importantes elementos da história da economia rural do Brasil, notadamente, da cultura cafeeira.

É relevante, portanto, ampliar o debate sobre o tema da preservação da paisagem cultural, pois, este enquanto forma inovadora, ensejará novas formas de proteção e de gestão do patrimônio.

\section{BIBLIOGRAFIA}

BAHIA, Cláudio Listher Marques. (2014). Identidade, lugar e paisagem cultural. In: $3^{\circ}$ Colóquio Iberoamericano paisagem cultural, patrimônio e projeto - desafios e perspectivas, 2014, Belo Horizonte. Anais... Belo Horizonte: Universidade Federal de Minas Gerais.

CAPEL, Horacio. (2002). La morfología de las ciudades. Barcelona: Ediciones del Serbal, 2002. [v.l Sociedad, cultura y paisaje urbano.]

CASTRIOTA, Leonardo Barci. (2007). Intervenções sobre o Patrimônio urbano: modelos e perspectivas. Revista Fórum Patrimônio: amb. constr. e patr. sust., Belo Horizonte,v.1,n.1,set./dez. Disponível em: http://portal.iphan.gov.br/uploads/ckfinder/arquivos/CASTRIOTA\%252c\%20Leonardo\%20B_\%20Interve nções\%20sobre\%200\%20patrimônio\%20urbano\%20-\%20modelos\%20e\%20perspectivas.pdf>. Acessado em 12 de jan. 2017.

Centro de Comércio de Café de Vitória (CCCV). (2017). Institucional: o café. Disponível em: < http://www.cccv.org.br/institucional/historia-cafe/ >. Acessado em 20 de abr. 2017.

CLAVAL, Paul. (2007). A geografia cultural. Florianópolis: Editora UFSC.

CUNHA, Francisco Manoel da. (1844). Informação que Francisco Manoel da Cunha deu sobre a província, então capitania, do Espírito Santo, ao ministro de Estado Antônio de Araújo Azevedo, 23/6/1811. In: Revista do Instituto Histórico e Geográfico do Brasil, 6:461-466.

BRANDI, Cesari. (2004). Teoria da Restauração. Cotia, SP: Atelie Editorial.

IBGE (INSTITUTO BRASILEIRO DE GEOGRAFIA E ESTATÍSTICA). (2007). Cidades. Disponível em http://www.ibge.gov.br/cidadesat/default.php. Acessado em julho de 2008.

IBGE (INSTITUTO BRASILEIRO DE GEOGRAFIA E ESTATÍSTICA). (1985). Coleção Monografias Municipais. Nova Série, $\mathrm{n} 299$, set..

IPHAN (INSTITUTO DO PATRIMÔNIO HISTÓRICO E ARTÍSTICO NACIONAL). (1995). Recomendação Europa. Disponível em: <http://portal.iphan.gov.br/uploads/ckfinder/arquivos/Recomendacao\%20Europa\%201995.pdf>. Acessado em 12 jan. 2017.

(2014). Paisagem Cultural. Disponível em: < http://portal.iphan.gov.br/pagina/detalhes/899/>. Acessado em 12 jan. 2017.

LOBATO, Ana Bettero Monteiro. (1968) .Folclore. Revista Vitória, ano XIX, nº 84, janeiro/junho.

(2014). PAC Cidades Históricas. Disponível em: < http://portal.iphan.gov.br/pagina/detalhes/235 >. Acessado em 20 de abr. 2017.

MENDONÇA, Paulo Henriques de. Muqui. Cidade Menina, 1850-1989. (1989). Vitória, SAGRAF Artes Gráficas Ltda.

NASCIMENTO, Flávia Brito do; SCIFONI, Simone. (2010). A paisagem cultural como novo paradigma para a proteção: a experiência do Vale do Ribeira-SP. Revista CPC, São Paulo, n. 10, p. 29-48, maio/out. Dísponivel em: <http://portal.iphan.gov.br/uploads/ckfinder/arquivos/Texto\%205\%20\%20NASCIMENTO\%20e\%20SCIFONI.pdf. >. Acessado em 15 jan. 2017

RAMBALDUCCI, Ney Costa. (1991). Muqui. Passado de Glória, Futuro de Esperança. Rio de Janeiro, Edições Achiamé Ltda. 
RUBIM, Brás da Costa. (1862). Dicionário topográfico da província do Espírito Santo. In Revista do Instituto Histórico e Geográfico do Brasil. Tomo XXV, p. 597-648.

RUBIM, Francisco Alberto. (1900). Memória estatística da província do Espírito Santo no ano de 1817. Revista do Instituto Histórico e Geográfico do Brasil, Rio de Janeiro, Tomo XIX (terceira série), p. $161-84$.

SEBRAE (SERVIÇO DE APOIO A MICRO E PEQUENAS EMPRESAS). (2005). Inventário da Oferta Turística do Município de Muqui/2005. Espírito Santo. Governo do Estado do Espírito Santo.

SECRETARIA DE ESTADO DE CULTURA DO ESTADO DO ESPÍRITO SANTO (SECULT). (2012). RESOLUÇÃO CEC N 003/2012 - Dispõe sobre a regulamentação das diretrizes para intervenções nos espaços públicos, lotes e edificações integrantes da Área de Proteção do Ambiente Cultural de Muqui. Vitória Espírito Santo, SECULT. Disponível em: < http://secult.es.gov.br/_midias/pdf/resolucao_cec_03_2012_normativa_muqui_does-899752cd9113c3d46.pdf >. Acessado em 13 de jan. 2017.

SCIFONI, Simone. (2016). Paisagem cultural. In: GRIECO, Bettina; TEIXEIRA, Luciano; THOMPSON, Analucia (Orgs.). Dicionário IPHAN de Patrimônio Cultural. 2. ed. rev. ampl. Rio de Janeiro, Brasília: IPHAN/DAF/Copedoc. (verbete).

SOUZA, Alfredo; PESSOTTI, Luciene. (2008). Levantamento Histórico e Diagnóstico Urbanístico e Arquitetônico do Sítio Histórico de Muqui - Espírito Santo, Brasil. Vitória: 21 SR IPHAN.

PESSOTTI, Luciene. (2014). Arquitetura Cafeeira do Sul do Espírito Santo: o casario histórico de Muqui. In: III Encontro da Associação Nacional de Pesquisa e Pós-graduação em Arquitetura e Urbanismo, arquitetura, cidade e projeto: uma construção coletiva, São Paulo. Anais... São Paulo, 1-10.

PESSOTTI, Luciene. (2010). Inventário de Conhecimento de Muqui. Vitória: SECULT-ES; SINCADES, 2010.

WEISSHEIMER, Maria Regina (org.). (2009) Paisagem Cultural - IPHAN. Brasília: DEPAM -IPHAN. 